\title{
Pengembangan Media Maze Alur Tulis pada Perkembangan Motorik Halus
}

\author{
Anif Umi Munawaroh, Arwendis Wijayanti \\ PG PAUD STKIP Modern Ngawi \\ anifumi250@gmail.com, arwendis.wijayanti@gmail.com
}

\begin{abstract}
Abstrak
Penelitian ini bertujuan untuk mendiskripsikan dan memberikan gambaran tentang kepraktisan dan keefektifan media Maze Alur Tulis pada perkembangan Motorik Halus Anak Usia Dini. Dimana hasil penelitian ini pada akhirnya diperoleh data yang menggambarkan kepraktisan dan keefektifan media Maze Alur Tulis pada perkembangan Motorik Halus Anak Usia Dini. Penelitian ini merupakan penelitian pengembangan yang mengacu pada model pengembangan (research and development) Borg \& Gall. Berdasarkan data yang diperoleh menunjukan bahwa media Maze Alur Tulis layak digunakan sebagai penunjang kegiatan belajar. Hal ini ditunjukkan dari beberapa penilaian yang telah dilakukan $100 \%$ anak dapat melakukan kegiatan I; (2) 93,75\% anak dapat melakukan kegiatan II; (3) 87,5\% anak dapat melakukan kegiatan III; (4) 94,78\% anak mudah melakukan kegiatan; (5) $96,85 \%$ anak aman dalam melakukan kegiatan bermain dengan media maze alur tulis; (6) $98,9 \%$ anak merasa senang saat bermain dengan media maze alur tulis. Produk ini dapat digunakan sebagai salah satu alternatif media pembelajaran yang menarik bagi anak, dapat membuat anak akti, kreatif dan menyenangkan dan Layak untuk digunakan.
\end{abstract}

Kata Kunci: Perkembangan Motorik Halus, Maze, Alur Tulis, Kelompok A, Pengembangan Media Pembelajaran.

\section{PENDAHULUAN}

Proses pendidikan terjadi apabila antar komponen pendidikan berlaku sebagai sebuah sistem. Tujuan pendidikan, isi pendidikan, metode pendidikan, pendidik, peserta didik/anak didik, lingkungan (orang tua, masyarakat dan sekolah), kualitas pembelajaran, media pembelajaran, dan evaluasi pembelajaran serta kurikulum merupakan komponen pendidikan yang ikut serta berperan dalam mewujudkan tercapainya tujuan pendidikan. Media pembelajaran merupakan salah satu komponen yang mendukung keberhasilan terlaksananya proses pendidika

Tujuan menghadirkan media pembelajaran juga untuk menciptakan terjadinya proses belajar yang bermakna. Menurut Hamdani (2011) bahwa, "Media pembelajaran dalam proses belajar mengajar dapat membangkitkan keinginan dan minat yang baru, membangkitkan motivasi dan rangsangan kegiatan belajar, bahkan membawa pengaruhpengaruh psikologi terhadap siswa".
Berdasarkan observasi awal yang dilakukan pada tanggal 12-13 Desember 2018, diperoleh data bahwa Taman Kanak-kanak Dharma Wanita Sumber telah menerapkan pembelajaran Kurikulum 2013 mulai semester 1 Tahun Ajaran 2016/2017.

Penerapan kurikulum 2013 di Taman Kanak-kanak belum berjalan lancar, terdapat kendala dalam pelaksanaan kurikulum ini salah satunya seperti keterbatasan media pembelajaran sebagai sumber belajar. Media yang biasa digunakan guru dalam pembelajaran adalah media visual (modul tematik, buku cerita dan poster), alat peraga, alat permainan edukatif, media audio, serta contoh-contoh benda konkret dan juga alam sekitar taman bermain mereka. Tetapi belum semua media terintegrasi dengan kurikulum 2013.

Modul tematik-saintifik dari pemerintah tersebut menyajikan aktivitas-aktivitas permainan menarik yang mengembalur tulisn dan mengasah aspek-aspek perkembangan anak, meliputi afektif, kognitif, bahasa dan psikomotorik. Aktivitas dalam pembelajaran 
menggunakan modul disajikan secara tematik dengan pendekatan saintifik, sehingga anak dapat belajar dengan maksimal sesuai perkembangannya, serta menanamkan nilai-nilai pendidikan budaya dan karakter bangsa yang terintregasi dalam setiap aktivitas (Tjitji Wartisah, 2015).

Salah satu kegiatan pembelajaran yang masih sering memiliki kendala adalah pembelajaran mengenai materi alur tulis menggunakan motorik halus anak. Materi alur tulis penting dikenalkan pada anak didik, bertujuan agar anak-anak mampu mengenal alur tulis dan mengetahui abjad-abjad bacaan yang ada di sekitar mereka kelak nanti. Pengenalan alur tulis pada kelompok A adalah alur tulis huruf vokal dan konsonan. Guru biasanya menggunakan media modul alur tulis menggunakan motorik halus anak menggunakan benda-benda di sekitar belajar mereka sebagai sumber belajar alur tulis. Hal ini dikarenakan media pembelajaran sebagai sumber belajar mengenai alur tulis di Taman Kanak-kanak Dharma Wanita Sumber masih terbatas, terutama media pembelajaran berupa Alat Permainan Edukatif (APE).

Berdasarkan hasil pengamatan dan wawancara yang dilakukan kepada dua orang guru kelas di TK Dharma Wanita Sumber, khususnya pada pembelajaran fisik motorik diperoleh data: (1) jumlah anak di kelompok A adalah 17 anak, yang terdiri dari kelas berjumlah 14 anak perempuan dan 3 anak lakilaki dan 15 anak yang terdiri dari 8 anak perempuan dan 7 anak laki-laki (2) untuk kegiatan aspek perkembaangan motorik halus yang pertama, anak belum dapat membuat garis vertikal, horizontal,lengkung kiri/kanan,miring kiri/kanan dan lingkaran dengan presentase $81,25 \%$ belum mampu (3) sedalur tulisn dala mengkoordinasi mata dan tangan untuk melakukan gerakan yang rumit ada $87,50 \%$ anak yang belum mampu (4) dan pada aspek perkembangan mengontrol gerakan tangan yang menggunakan otot halus (menjumput, mengelus, mencolek, mengepal, melintir, memilin, memeras ada $75,00 \%$ anak yang masih kurang mampu. Kemungkinan hal ini karena sudah pernah menerapkan kegiatan pembelajaran yang didesain melalui media namun masih ada beberapa anak yang tidak mau berpartisipasi dan tidak mematuhi peraturan media yang ada.

Berdasarkan permasalahan di atas, perlu adanya pengembangan motorik halus yang efektif, menarik dan menyenangkan, yang dapat dilakukan oleh anak. Dimana aktif dimaksudkan bahwa dalam proses pembelajaran guru harus menciptakan suasana sedemikian rupa sehingga siswa aktif bertanya, mempertanyakan, dan mengemukakan gagasan. Belajar memang merupakan suatu proses aktif dari si pembelajar dalam membangun pengetahuannya, bukan proses pasif yang hanya menerima kucuran ceramah guru tentang pengetahuan. Jika pembelajaran tidak memberikan kesempatan kepada siswa untuk berperan aktif, maka pembelajaran tersebut bertentangan dengan hakikat belajar.

Peran aktif dari siswa sangat penting dalam rangka pembentukan generasi yang kreatif, yang mampu menghasilkan sesuatu untuk kepentingan dirinya dan orang lain. Kreatif juga dimaksudkan agar guru menciptakan kegiatan belajar yang beragam sehingga memenuhi berbagai tingkat kemampuan siswa.

Menyenangkan adalah suasana belajarmengajar yang menyenangkan sehingga siswa memusatkan perhatiannya secara penuh pada belajar sehingga waktu curah perhatiannya ("time on task") tinggi. Menurut hasil penelitian, tingginya waktu curah perhatian terbukti meningkatkan hasil belajar. Selain itu, pembelajaran fisik motorik yang optimal juga harus dapat memperhatikan komponenkomponen perkembangan motorik halus. Pembelajaran yang dapat dikembalur tulisn di Taman Kanak-kanak dan dapat membuat anak senang dan mudah melakukannya serta aman bagi anak adalah pembelajaran fisik motorik berupa media yang akan dilakukan di TK A Dharma Wanita Sumber.

Penerapan pengembangan motorik halus khususnya media yang sesuai dengan karakteristik anak akan memudahkan peserta didik untuk melakukan kegiatan pembelajaran, termasuk pengembangan keterampilan motorik halus. Salah satu media yang dapat digunakan dalam mengembangkan motorik halus adalah alat media edukatif maze alur tulis. Maze alur 
tulis merupakan alat media edukatif yang terbuat dari kayu dan berisi beberapa bentuk alur, diantaranya: zig-zag, gelombang kecil, gelombang besar, variasi I (miring dan datar) dan variasi II (lengkung, datar, tegak, dan miring). Diperuntukkan bagi anak usia dari 4-5 tahun untuk menstimulasi keterampilan motorik halus, kelentukan jari-jemari dan koordinasi mata dengan tangan sehingga anak siap belajar menggambar, melukis dan menulis permulaan.

\section{Kemampuan Motorik Halus}

Kemampuan berasal dari kata mampu yang berarti kuasa (bisa, sanggup) melakukan sesuatu, sedangkan kemampuan berarti kesanggupan, kecakapan, kekuatan (Tim Penyusun Kamus Besar Bahasa Indonesia, 1989). Kemampuan (ability) berarti kapasitas seorang individu untuk melakukan beragam tugas dalam suatu pekerjaan. (Stephen P. Robbins \& Timonthy A. Judge, 2009).

Yudha M. Saputra \& Rudiyanto (2005) perkembangan merupakan istilah umum yang mengacu pada kemajuan dan kemunduran yang terjadi sepanjang hayat. Pertumbuhan berkaitan dengan perubahan fungsi pada perkembangan. Jadi perkembangan meliputi semua aspek dari perilaku manusia, dan sebagai hasil yang hanya dapat dipisahkan dalam periode usia. Dukungan pertumbuhan terhadap perkembangan sepanjang hidup merupakan sesuatu yang berarti.

Oleh karena itu perlu perkembangan motorik sejak usia dini. Keterampilan juga dibutuhkan dalam rangka mempersiapkan anak di masa depan. Menurut Yudha dan Rudiyanto (2005) keterampilan adalah kemampuan anak dalam melakukan berbagai aktivitas seperti motorik, bahasa, sosial- emosional, kognitif dan afektif (nilai-nilai moral). Keterampilan yang dipelajari dengan baik akan berkembang menjadi kebiasaan. Sedangkan dalam Kamus Besar Bahasa Indonesia (2008) keterampilan adalah kecakapan untuk menyelesaikan tugas. Jadi dapat disimpulkan bahwa keterampilan adalah kemampuan anak dalam melakukan berbagai aktivitas dalam usahanya untuk menyelesaikan tugas.

Dini P. Daeng Sari (1996) menyatakan bahwa motorik halus adalah aktivitas motorik yang melibatkan aktivitas otot-otot kecil atau halus, gerakan ini lebih menuntut koordinasi mata dan tangan serta kemampuan pengendalian gerak membedakan berbagai bentuk, bangun, warna, ukuran, arah. yang baik, yang memungkinkan untuk melakukan ketepatan dan kecermatan dalam gerakangerakannya.

Kemampuan motorik halus dapat dilatih dan dikembangkan melalui kegiatan seperti bermain puzzle, menyusun balok, memasukan benda ke dalam lubang sesuai bentuknya, membuat garis, melipat kertas, menjahit dan sebagainya. Sumantri menyatakan keterampilan motorik halus adalah pengorganisasian penggunaan sekelompok otot-otot kecil seperti jari-jemari dan tangan yang sering membutuhkan kecermatan dan koordinasi mata dengan tangan, keterampilan yang mencakup pemanfaatan dengan alat-alat untuk bekerja dan obyek yang kecil dan atau pengontrolan terhadap mesin misalnya mengetik, menjahit dan lain-lain.

Kemampuan motorik halus adalah kesanggupan melakukan gerakan yang melibatkan koordinasi mata dan otot-otot kecil seperti keterampilan menggunakan jari jemari dan pergelangan tangan yang cermat dan tepat. Dan motorik halus itu dapat mengembangkan kemampuan anak untuk dapat membuat garis vertikal, horizontal,lengkung kiri/kanan,miring kiri/kanan dan lingkaran. Dapat mengkoordinasi mata dan tangan untuk melakukan gerakan yang rumit. Dapat mengontrol gerakan tangan yang menggunakan otot halus (menjumput, mengelus, mencolek, mengepal, melintir, memilin, memeras).

Sedangkan menurut John W. Santrok (2007) menyatakan bahwa motorik halus anak 
Taman Kanak-kanak ditekankan pada koordinasi gerakan motorik halus dalam hal ini berkaitan dengan meletakkan atau memegang suatu obyek dengan menggunakan jari tangan. Saat usia 4 tahun koordinasi gerakan motorik halus anak sangat berkembang bahkan hampir sempurna, sedangkan saat usia 5 tahun koordinasi gerakan motorik halus berkembang pesat. Pada masa ini anak telah mampu mengkoordinasikan gerakan mata dengan tangan, lengan, dan tubuh secara bersama.

Sumantri (2005) menyatakan bahwa keterampilan motorik halus adalah pengorganisasian penggunaan kelompok otototot kecil seperti jari dan tangan yang sering membutuhkan kecermatan dan koordinasi mata dengan tangan, keterampilan yang mencakup pemanfaatan menggunakan alat-alat untuk mengerjakan suatu objek.

Keterampilan motorik halus adalah kemampuan anak untuk melakukan aktivitas melalui penggunaan otot-otot kecil mengontrol tangan, jari dan ibu jari atau anggota tubuh tertentu dengan kecermatan dam koordinasi yang baik seperti keterampilan menggunakan tangan dengan tepat. Keterampilan motorik halus ini dapat dilatih dan dikembangkan melalaui kegiatan dan rangsangan yang berkelanjutan dan rutin.

Berdasarkan pendapat diatas mengenai Pengembangan Media Maze Alur Tulis pada Perkembangan Motorik Halus Anak Kelompok A TK Dharma Wanita Sumber dapat disimpulkan bahwa motorik halus adalah aktifitas motorik yang melibatkan otot-otot kecil yang mana gerakannya lebih menuntut koordinasi mata dengan tangan dan melibatkan koordinasi syaraf otot. Kemampuan motorik halus adalah kemampuan yang berhubungan dengan keterampilan fisik yang melibatkan otot kecil dan koordinasi mata dan tangan. Untuk mengembangkan keterampilan ada tiga hal yang penting yaitu kesempatan untuk berlatih, rangsangan untuk belajar, contoh yang baik untuk ditiru dan bimbingan yang baik untuk meyakinkan bahwa peniruan yang dilakukan itu benar.

Pengembangan Media Maze Alur Tulis pada Perkembangan Motorik Halus Anak Kelompok A TK Dharma Wanita Sumber dapat disimpulkan bahwa motorik halus adalah aktifitas motorik yang melibatkan otot-otot kecil yang mana gerakannya lebih menuntut koordinasi mata dengan tangan dan melibatkan koordinasi syaraf otot. Kemampuan motorik halus adalah kemampuan yang berhubungan dengan keterampilan fisik yang melibatkan otot kecil dan koordinasi mata dan tangan. Untuk mengembangkan keterampilan ada tiga hal yang penting yaitu kesempatan untuk berlatih, rangsangan untuk belajar, contoh yang baik untuk ditiru dan bimbingan yang baik untuk meyakinkan bahwa peniruan yang dilakukan itu benar.

Sumantri (2005), menunjukkan indikator perkembangan motorik halus anak berdasarkan kronologi usia, yaitu: Usia 4 Tahun: a) Membangun menara setinggi 11 kotak, b) Membangun sesuatu yang berarti bagi anak tersebut dan gambar tersebut dapat dikenali orang lain, c) Mempergunakan gerakan-gerakan jemari dalam permainan jemari, d) Menjiplak gambar kotak, e) Menulis beberapa huruf. Usia 5 Tahun: a) Menulis nama depan, b) Membangun menara setinggi 12 kota, c) Mewarnai dengan garis-garis,d) Memegang pensil dengan benar antara ibu jari dan dua jari, e) Menggambar orang beserta rambut dan hidung , f) Menjiplak persegi panjang dan segitiga.

\section{Media Maze Alur Tulis}

Maze merupakan game sederhana yang bertujuan menentukan jalur yang tepat untuk mencapai tujuan yang telah ditetapkan. Dalam permainan maze anak-anak harus menemukan jalur pada bagian -bagian maze berupa kotakkotak yang dilewati untuk tiap baris atau tiap 
kolom. (Kurniawan, 2010:iii ) Irawan (2009:2) mengatakan bahwa terdapat beberapa bentuk maze seperti maze untuk anak-anak seperti berbentuk lingkaran, mencari jejak rumah, menemukan jalan keluar untuk ke sekolah dan lain-lain.

Bentuk-bentuk maze untuk anak TK yang akan digunakan dalam penelitian ini dapat dlihat pada lampiran 2.1. Istiaty (2006:12) mengemukakan bahwa permainan mencari jejak atau maze adalah usaha melakukan penemuan artinya permainan dapat menghasilkan ciptaan baru anak dalam usia berapapun, di mana saat ikut dalam suatu permainan sedang menciptakan sesuatu yang baru, sesuatu yang berlum pernah dilakukan sebelumnya. Permainan maze adalah permainan edukatif dengan jalan sempit yang berliku dan berbelok dan kadang kala merupakan jalan buntu ataupun jalan yang mempunyai halangan, dapat juga dikatakan permainan mencari jalan keluar kemudian bagaimana anak bisa menemukan jalan keluarnya.

Depdiknas (2006:2) menjelaskan pengertian maze adalah mencari jejak yaitu suatu kegiatan untuk mencari, menelusuri dan memilih jalan menuju tempat yang ditentukan dengan memakai media tertentu. Kegiatan ini digemari anak-anak karena dapat memberikan nilai positif dalam pengembangan daya pikir dan kecermatan serta keterampilan.

Kamus Besar Bahasa Inggris-Indonesia (1995) maze adalah jalan yang bersimpang atau berliku-liku. Sedangkan menurut Fatih Ali (2014) maze alur tulis adalah papan alur yang mempunyai beberapa bentuk alur diantaranya zig-zag, gelombang kecil, gelombang besar, variasi I (miring dan datar) dan variasi II (lengkung, datar, tegak, dan miring). Senada dengan pendapat tersebut Asolihin (2012) menyatakan bahwa maze alur tulis adalah alat permainan edukatif yang terbuat dari kayu yang terdiri dari beberapa alur dan setiap alurnya memiliki warna yang bebeda-beda sehingga dapat menarik perhatian anak.

Maze alur tulis merupakan alat permainan edukatif yang sesuai untuk menstimulasi perkembangan motorik halus anak. Menurut Fatih Ali (2014) menyatakan bahwa kegunaan maze alur tulis antara lain: untuk menstimulasi keterampilan motorik halus, kelentukan jari-jemari dan koordinasi mata dengan tangan sehingga anak siap belajar menggambar, melukis dan menulis permulaan, melatih kesabaran, serta melatih mempelajari garis atau bentuk. Sedangkan menurut Asolihin (2012), manfaat maze alur tulis adalah untuk anak yang sedang belajar menggambar, melukis dan menulis permulaan. Berdasarkan kedua pendapat tersebut maka dapat disimpulkan bahwa manfaat maze alur tulis adalah untuk menstimulasi keterampilan motorik halus, kelentukan jari-jemari dan koordinasi mata dengan tangan sehingga anak siap belajar menggambar, melukis dan menulis permulaan.

\section{METODE}

Dalam melaksanakan pengembangan maze alur tulis pada perkembangan motorik halus ini, maka jenis penelitian yang dipergunakan adalah penelitian model pengembangan (research and development). Penelitian dan pengembangan atau dalam bahasa Inggrisnya Research and Development adalah "suatu proses atau langkah-langkah untuk mengembangkan suatu produk baru atau menyempurnakan produk yang telah ada, yang dapat dipertanggung jawabkan" (Sukmadinata, 2009:164).

Pengembangan Media Maze Alur tulis Pada Pembelajaran Motorik Halus Anak Kelompok A di TK Dharma Wanita Sumber ini menggunakan model pengembangan dari Borg \& Gell (1983) yang terdiri dari sepuluh langkah. Prosedur penelitian dan pengembangan dari Borg and Gall tersebut bukanlah merupakan 
suatu prosedur yang baku dalam sebuah penelitian.

Karena penelitian dan pengembangan ini hanya dilakukan dalam 1 sekolah yaitu di TK Dharma Wanita Sumber dan subjek yang digunakan hanya 32 anak, maka untuk langkah kedelapan sampai dengan kesepuluh tidak dilaksanakan, sehingga langkah penelitian dan pengembangan ini dimodifikasi, meliputi:

(1) Penelitian dan pengumpulan data (research and information collecting). Pengukuran kebutuhan, studi literatur, penelitian dalam skala kecil, dan pertimbangan-pertimbangan dari segi nilai;

(2) Perencanaan (planning). Menyusun rencana penelitian, meliputi kemampuan-kemampuan yang diperlukan dalam pelaksanaan penelitian, rumusan tujuan yang hendak dicapai dengan penelitian tersebut, desain atau langkah-langkah penelitian, kemungkinan pengujian dalam lingkup terbatas;

(3) Pengembangan draf produk (develop preliminary form of product). Pengembangan bahan pembelajaran, proses pembelajaran dan instrumen evaluasi;

(4) Uji coba lapangan awal (preliminary field testing). Uji coba dilapangan pada 1 sampai 3 sekolah dengan 6 sampai 12 subjek uji coba (guru). Selama uji coba diadakan pengamatan, wawancara dan pengedaran angket;

(5) Merevisi hasil uji coba (main product revision). Memperbaiki atau menyempurnakan hasil uji coba;

(6) Uji coba lapangan (main field testing). Melakukan uji coba yang lebih luas pada 5 sampai dengan 15 sekolah dengan 30 sampai dengan 100 orang subjek uji coba. Data kuantitatif penampilan guru sebelum dan sesudah menggunakan model yang dicobakan dikumpulkan. Hasil-hasil pengumpulan data dievaluasi dan kalau mungkin dibandingkan dengan kelompok pembanding;

(7) Penyempurnaan produk hasil uji lapangan (operasional product revision). Menyempurnakan produk hasil uji lapangan;

(8) Uji pelaksanaan lapangan (operasional field testing). Dilaksanakan pada 10 sampai 30 sekolah melibatkan 40 sampai dengan 200 subjek. Pengujian dilakukan melalui angket, wawancara, dan observasi dan analisis hasilnya; (9) Penyempurnaan produk akhir (final product revision). Penyempurnaan didasarkan masukan dari uji pelaksanaan lapangan; (10) Diseminasi dan implementasi (dissemination and implementation). Melaporkan hasilnya dalam pertemuan profesional dan dalam jurnal. Bekerjasama dengan penerbit untuk penerbitan. Memonitor penyebaran untuk pengontrolan kualitas.

Dengan wilayah penelitian dilakukan di desa Sumber, Pangkur, Ngawi. Populasi dalam penelitian ini adalah seluruh kelompok A dengan jumlah 32 anak TK Dharma Wanita Sumber Pangkur Ngawi kelompok usia 4-5 tahun yang memanfaatkan media pembelajaran khususnya dalam mengembangkan motorik halus. Dengan sampel penelitian anak kelompok A TK Dharma Wanita Sumber Pangkur Ngawi kelompok usia 4-5 tahun.

Metode pengumpulan data menggunakan metode observasi dan wawancara. Sedangkan analisis data mengunakan analisis data kualitatif berupa saran dan masukan dari para ahli yang digunakan untuk melakukan revisi terhadap rancangan produk serta merupakan teknik analisis deskriptif. Serta analisis data kuantitatif berupa persentase hasil evaluasi para ahli, persentase keamanan, kemudahan, dan kesenangan anak pada saat melakukan kegiatan dan persentase motorik halus.

\section{HASIL DAN PEMBAHASAN}

Berdasarkan pengumpulan data dari kajian uji coba Pengembangan Media Maze Alur Tulis pada Perkembangan Motorik Halus Anak Kelompok A di TK Dharma Wanita Sumber di bawah ini:

1. Berdasarkan dari tinjauan para ahli, maka rancangan produk keseluruhan permainan yang dibuat, direvisi dan dikonsultasikan pada ahli fisik motorik anak usia dini dan ahli pembelajaran pendidikan anak usia dini, dan ahli media pembelajaran anak usia dini, yang kemudian digunakan sebagai dasar untuk memperbaiki kualitas produk 
pengembangan, sebelum memasuki tahap uji coba kelompok kecil.

2. Hasil analisis data uji coba kelompok kecil terhadap 10 anak kelompok A di TK Dharma Wanita Sumber diperoleh penilaian sebanyak 83,3\% anak mudah melakukan kegiatan dengan media Maze Alur Tulis, $86,6 \%$ anak merasa aman melakukan kegiatan menggunakan media Maze Alur Tulis, 93,3\% anak merasa senang melakukan kegiatan permainan Maze Alur Tulis, serta dalam aspek fisik motorik diperoleh 92,25\% anak dapat melakukan semua kegiatan dengan media Maze Alur Tulis dengan baik dan benar.

3. Hasil analisis data uji coba kelompok besar terhadap 32 anak kelompok A di TK Dharma Wanita Sumber diperoleh penilaian sebanyak 94,78\% anak mudah melakukan kegiatan menggunakan media Maze Alur Tulis, 96,85\% anak merasa aman melakukan kegiatan menggunakan media Maze Alur Tulis, 98,9\% anak merasa senang melakukan kegiatan menggunakan media Maze Alur Tulis, serta dalam aspek fisik motorik diperoleh $96,87 \%$ anak dapat melakukan semua kegiatan menggunakan media Maze Alur Tulis dengan baik dan benar.

Media maze alur tulis ini terbuat dari bahan-bahan yang mudah di dapat di lingkungan sekitar. Kemudian media maze alur tulis ini juga mempunyai pola alur yang mengikuti sketsa huruf vokal maupun konsonan. Media ini juga memiliki gambargambar yang menarik, serta pion di maze ini juga mudah untuk di pegang anak.

Bilamana media maze ini sudah dapat di gunakan oleh anak sebagai media permainan yang menarik. Serta media ini daya pakainya dapat bertahan lama dan aman bagi anak, maka media ini telah mencapai tahap keberhasilan sebagai media pembelajaran edukatif untuk anak usia dini. Media tersebut dikembangkan pada perkembangan motorik halus anak agar semakin optimal lagi.

Setelah produk awal Media Maze Alur Tulis telah jadi, kemudian rancangan produk awal Media divalidasi guna menemukan kekurangan serta mendapatkan saran dan masukan yang dapat meningkatkan kualitas produk dari beberapa ahli. Maka dilakukan validasi oleh ahli materi serta ahli media. Ahli materi untuk menilai dari segi konten materi yang disajikan, kesesuaian materi, cakupan materi yang dimuat dan lain-lain.

Dalam tahap pembuatan media ini mempertimbangkan juga aspek saran dan masukan dari ahli materi motorik halus dan ahli media. Adapun saran dan masukan dari ahli materi di antaranya : (1) Penyampaian kegiatan dibuat menarik diselingi kegiatan yang lain sehingga anak tidak bosan jika hanya bermain dengan papan maze saja. (2) Kegiatan evaluasi setelah bermain maze sebaiknya ditambah dengan menebalkan atau menulis ulang alur huruf yang sama dengan papan maze.kemudian saran dan masukan dari ahli media di antaranya yaitu: (1) Media dari triplek lebih diperkecil dan diperhalus. (2) Kertas gambar hakikatnya terbuat dari bahan yang awet.

Maze alur tulis merupakan alat permainan edukatif yang sesuai untuk menstimulasi perkembangan motorik halus anak. Menurut Fatih Ali (2014) menyatakan bahwa kegunaan maze alur tulis antara lain: untuk menstimulasi keterampilan motorik halus, kelentukan jari-jemari dan koordinasi mata dengan tangan sehingga anak siap belajar menggambar, melukis dan menulis permulaan, melatih kesabaran, serta melatih mempelajari garis atau bentuk. Sedangkan menurut Asolihin (2012), manfaat maze alur tulis adalah untuk anak yang sedang belajar menggambar, melukis dan menulis permulaan. Berdasarkan kedua pendapat tersebut maka dapat disimpulkan bahwa manfaat maze alur tulis adalah untuk menstimulasi keterampilan motorik halus, 
kelentukan jari-jemari dan koordinasi mata dengan tangan sehingga anak siap belajar menggambar, melukis dan menulis permulaan.

Hasil rancangan produk media ini merupakan papan yang digunakan berukuran panjang $25 \mathrm{~cm}$ dan lebar $20 \mathrm{~cm}$. Papan ini dilengkapi dengan 10 pin dengan warna berbeda yang digunakan untuk mencocokan gambar dengan gabungannya yang terdapat pada lembar materi. Setiap media maze berbentuk alur sesuai bentuk huruf vokal a-i-ue-o. Setiap media maze berbentuk alur sesuai bentuk huruf a-z. Materi yang digunakan disesuaikan dengan tema yang mengacu pada kurikulum diantaranya:

a. Tema buah-buahan

Pada tema ini anak diajak untuk mengenali berbagai macam buah-buahan yang sering dijumpai oleh anak. Anak dapat mengenali buah dengan mengidentifikasi huruf awal pada nama buah.

b. Tema binatang

Pada tema ini anak diajak untuk mengenali bermagai macam binatang mulai dari binatang ternak, binatang peliharaan, bahkan binatang buas. Anak dapat mengenali binatang dengan mengidentifikasi huruf awal pada nama binatang.

Langkah-langkah penggunaan media maze alur tulis pada kelompok A untuk mengembangkan kemampuan motorik halus sebagai berikut:
a) Persiapkan komponen maze alur tulis seperti papan.
b) Tentukan berapa anak yang dapat mengikuti permainan.
c) Sebelum memainkan permainan ini sebaiknya guru menjelaskan cara bermain maze alur tulis kepada anak
d) Anak di minta untuk memegang pion masing-masing.

e) Cocokan gambar dengan kata yang terdapat pada papan menggnakan pion warna yang telah disediakan.

f) Setelah semuanya sudah berjalan di lihat anak mana yang terlebih dulu sampai pada tujuan dan sesuai dengan alur yang benar.

Pada penelitian dan pengembangan yang dilakukan oleh peneliti di TK A Dharma Wanita Sumber dengan judul Pengembangan Media Maze Alur tulis di TK A Dharma Wanita Sumber, adapun tujuh langkah-langkah yang digunakan adalah:

1. Melakukan penelitian dan pengumpulan informasi (kajian pustaka, pengamatan kelas, persiapan laporan pokok persoalan).

2. Menyusun perencanaan berupa penyusunan rancangan produk media Maze Alur tulis (penyusunan aktivitas fisik motorik, perumusan tujuan dan penentuan urutan pembelajaran), dan untuk dievaluasi ahli.

3. Mengembangkan bentuk produk awal berupa "Media Maze Alur tulis" untuk dievaluasi oleh ahli pembelajaran anak usia dini, ahli media pembelajaran anak usia dini dan ahli fisik motorik.

4. Melakukan uji coba lapangan permulaan/uji kelompok kecil terhadap 8 anak kelompok A di TK Dharma Wanita Sumber.

5. Merevisi produk awal berdasarkan hasil uji coba lapangan permulaan/uji kelompok kecil untuk melakukan uji lapangan utama sesuai dengan saran-saran hasil uji lapangan permulaan.

6. Melakukan uji lapangan utama di TK A Dharma Wanita Sumber dengan jumlah anak 32 anak.

7. Merevisi produk berdasarkan saran-saran hasil uji lapangan utama.

Berdasarkan permasalahan yang ada dikelompok A TK Dharma Wanita Sumber yang telah dijabaran sebelumnya, perlu adanya pengembangan kemampuan motorik halus yang efektif, menarik dan menyenangkan, yang dapat dilakukan di luar kelas. Selain itu, pembelajaran 
motorik halus yang optimal juga harus dapat memperhatikan komponen-komponen perkembangan motorik halus. Pembelajaran yang dapat dikembangkan di Taman Kanakkanak dan dapat membuat anak senang dan mudah melakukannya serta aman bagi anak adalah pembelajaran motorik halus anak dengan media yang tepat.

Adapun berdasarkan data yang telah dikumpulkan dari hasil analisis para ahli, ada beberapa bagian produk yang perlu direvisi. Hal ini dilakukan untuk memaksimalkan dari pembelajaran motorik halus anak melalui media maze alur tulis. Antara lain untu mengembangkan kemampuan motorik halus anak secara optimal maka harus diperhatikan kriteria media yang digunakan harus aman sesuai dengan jkarakteristik anak seperti perlunya diberikan tekstur kayu triplek yang halus, dan pion yang sesuai dengan ukuran jari anak, sehingga dalam bermain area tangan dan jari anak tidak dikhawatirkan dapat terluka dengan media tersebut. Kemudahan ukuran media maze alur tulis dan pion juga dibuat tidak terlalu besar sehingga mudah untuk dimainkan anak. Setelah revisi dilakukan, media maze alur tulis di uji coba kelompok kecil. Penyampaian kegiatan dibuat menarik diselingi kegiatan yang lain sehingga anak tidak bosan jika hanya bermain dengan papan maze saja. Kegiatan evaluasi setelah bermain maze sebaiknya ditambah dengan menebalkan atau menulis ulang alur huruf yang sama dengan papan maze. Media dari triplek lebih diperkecil dan diperhalus. Serta gambar hendaknya terbuat dari bahan yang awet. Setelah dilakukan revisi maka siap untuk melanjutkan pada tahap uji lapangan (kelompok Besar).

Pada pelaksanaan desain uji coba produk, tahap-tahap yang dikemukakan adalah desain uji coba, subyek uji coba, jenis data, instrument pengumpulan data dan teknik analisisnya. Hal ini dilakukan untuk mengetahui kelayakan produk yang akan dikembangkan dan dibuat.

Hasil analisis data uji lapangan kelompok Aesar, diperoleh presentase yaitu: (1) $100 \%$ anak dapat melakukan kegiatan I; (2) 93,75\% anak dapat melakukan kegiatan II; (3) $87,5 \%$ anak dapat melakukan kegiatan III; (4) 94,78\% anak mudah melakukan kegiatan; (5) 96,85\% anak aman dalam melakukan kegiatan bermain dengan media maze alur tulis; (6) 98,9\% anak merasa senang saat bermain dengan media maze alur tulis. Produk ini dapat diguakan sebagai salah satu alternatif media pembelajaran yang menarik bagi anak, dapat membuat anak akti, kreatif dan menyenangkan.

Adapun setelah produk mengalami tahap uji coba, maka produk atau media dapat memberikan solusi terhadap hambatanhambatan yang di alami guru yaitu:

1. Pembelajaran dapat aktif, kreatif, efektif dan menyenangkan di Taman Kanakkanak

2. Dapat terwujudnya pembelajaran yang mudah, aman dan menyenangkan dilakukan oleh anak.

\section{Kesimpulan}

Dengan melakukan tahap demi tahap penelitian mulai dari peninjauan para ahli, uji kelompok kecil dan uji lapangan (kelompok besar). Maka berdasarkan hasil dan pembahasan dapat disimpulkan sebagai berikut:

1. Media Maze Alur Tulis bisa dikatakan praktis pada perkembangan motorik halus anak karena telah memenuhi ketuntasan penilaian dalam hal kemudahan penggunaan, keamanan penggunaaan dan telah terpenuhi juga ketuntasan penilaian menyenangkan bagi anak.

2. Pada setiap penggunaan media dan keefektifan media Maze Alur Tulis pada perkembangan motorik halus anak telah memenuhi ketuntasan kelayakan sebesar $100 \%$. 


\section{DAFTAR PUSTAKA}

Arikunto Suharsimi (2010). Prosedur Penelitian Suatu Pendekatan Praktik. Jakarta: Rineka Cipta

Bambang Sujiono dkk. (2009). Metode Pengembangan Fisik. Jakarta: Universitas Terbuka.

Diyu Tatik. (2011). Peningkatan Kemampuan Motorik Halus Melalui Kegiatan Menjahit Dengan Metode Demonstrasi Pada Anak Kelompok B TK Jaya Lestari Desa Beliti Jaya. Jurnal, Kendari: IAIN Kendari.

Elizabeth B Hurlock. (1978). Perkembangan Anak. Jakarta: Airlangga

Mansur. (2005). Pendidikan Anak Usia Dini. Yogyakarta. Pustaka Pelajar

Musthofa,Yasin. (2007). EQ untuk anak usia dini dalam pendidikan Islam, Yogyakarta: Sketsa.

Santrock, John W. (2007). Psikologi Pendidikan Edisi Kedua. Jakarta: Prenada Media Group.

Sugiyono. (2017). Metode Penelitian Pendidikan: Kuantitatif, Kualitatif dan $R \& D$. Bandung. Alfabeta.

Tjitji Wartisah. 2015. Tematik-Saintifik Alat Komunikasi. Jakarta: Erlangga.

Ummu Atiyah. (2016).Pengembangan Alat Permainan Edukatif Maze "Papan Laju Warna” untuk Menstimulasi Kesiapan Membaca Anak Kelompok B TK ABA As-Salam Maredan Sendangtirto, Berbah, Sleman, di Yogyakarta. Skripsi, Yogyakarta: UNY Yogyakarta.. 